\title{
Mitos Kelas Menengah ke Atas dalam Desain Iklan Politik Risma- Bambang
}

\author{
Muh. Bahruddin \\ Program Studi Desain Komunikasi Visual, STIKOM Surabaya \\ Jalan Raya Kedung Baruk 98 Surabaya 60298 \\ Email: bahruddin@stikom.edu, muh.bahruddin@yahoo.com
}

\begin{abstract}
Abstrak
Pemilihan kepala daerah (pilkada) secara langsung di seluruh wilayah Indonesia berimbas pada hadirnya iklan politik para kandidat secara masif. Studi ini hendak mengkaji mitos kelas menengah ke atas dalam desain iklan politik Risma-Bambang yang memenangkan pilkada Surabaya 2010. Desain iklan politik ini menarik untuk dikaji karena memiliki konsep berbeda dengan desain iklan politik pada umumnya (out of mainstream). Jika desain iklan politik kandidat lain selalu menonjolkan gambar wajah kandidat yang besar untuk menarik minat calon pemilih, maka tidak demikian dengan desain iklan politik RismaBambang. Desain iklan politik Risma dan Bambang justru banyak menampilkan simbol-simbol yang disertai tagline "Not The Others". Dengan menggunakan analisis semiotika Roland Barthes, hasil kajian ini menunjukkan bahwa untuk menciptakan mitos kelas menangah ke atas di Surabaya, iklan politik Risma-Bambang dilabeli dengan simbol-simbol sandal selop, penguin, dan bacaan. Mitos ini diketahui setelah melakukan pembongkaran secara paradigmatik, sintagmatik, denotasi, dan konotasi dalam desain iklan politik Risma-Bambang. Mitos masyarakat kelas menengah ke atas dicitrakan dengan kecerdasan, santai, dan menyenangkan melalui simbol-simbol tersebut.
\end{abstract}

Kata kunci: Desain iklan politik, simbol, citra, dan mitos.

\begin{abstract}
Local elections (pilkada) in the entire territory of Indonesia affect the huge presence of the candidate's political advertising. This study examines myths about the middle to upper class in political advertising design of Risma-Bambang who won the mayoral election of Surabaya in 2010. This advertising design is interesting to study because it has a different concept of political advertising in general (out of the mainstream). The other candidate's political advertising design accentuate the face image in attracting potential voters in contras to political advertising design of Risma- Bambang that shous just a lot of display symbols that are accompanied with the tagline "Not The Others". Using a semiotic analysis from Roland Barthes, the results of this study indicate that in order to create the myth of middle to upper class in Surabaya, political advertising of Risma-Bambang has been labeled with the symbols of sandal slippers, penguin, and reading a book. This myth is known after doing an analysis of the paradigmatic, syntagmatic, denotation, and connotation in political advertising design of Risma-Bambang. The myth of the middle to upper class is imaged with intelligence, relaxing, and fun through these symbols.
\end{abstract}

Keywords: Political ad design, symbol, image, and myth.

\section{Pendahuluan}

Diberlakukannya pemilihan kepala daerah (pilkada) secara langsung oleh rakyat melalui pemilu, sebagaimana yang diamanatkan UU No 32/2004 tentang Pemerintahan Daerah dan PP No 6 Th 2005 tentang Pemilihan, Pengesahan Pengangkatan, dan Pemberhentian Kepala Daerah dan Wakil Kepala Daerah, berimbas pada masifnya iklan politik dari para kandidat. Studi ini mengkaji tentang desain iklan politik Risma-Bambang yang memenangkan pilkada Surabaya 2010. Pasangan Tri Rismaharini dan Bambang DH (Ridho) memperoleh suara 367.472 atau sebesar 40,9 persen.

Desain ini menarik untuk dikaji karena memiliki konsep berbeda dengan desain iklan politik pada umumnya (out of mainstream). Jika desain iklan politik kandidat lain selalu menonjolkan gambar wajah kandidat yang besar untuk menarik minat 
calon pemilih, maka tidak demikian dengan desain iklan politik Risma-Bambang. Desain iklan politik ini justru banyak menampilkan simbol-simbol yang disertai tagline seperti "Not The Others". Iklan politik ini seolah ingin melibatkan masyarakat dengan menyertakan kode-kode kultural sebagai simbol kelas menengah ke atas seperti yang tampak dalam billboard.

Sebagaimana yang dikatakan ketua tim pemenangan Risma-Bambang, Jagad Hariseno bahwa sasaran iklan tersebut adalah pemilih pemula dan kalangan menengah ke atas (Jawa Pos, 3 Maret 2010).

Desain-desain yang ditampilkan iklan politik Risma-Bambang menyangkut objek gaya hidup yang dicerminkan sebagai masyarakat metropolis seperti kegiatan yang bersifat rekreatif, bacaan, keceriaan, dan muda.

Gaya hidup sering dihubungkan dengan kelas sosial ekonomi dan menunjukkan citra seseorang. Gaya hidup orang ditunjukkan dalam variasi keputusan citra rasanya: mobil yang dikendarainya, keturunan anjing dan kucingnya, majalah yang dibacanya (atau setidaknya diletakkan pada meja kopinya), tempat mereka tinggal, bentuk rumahnya (besarnya, warna lantai, dan perabotannya), pekerjaannya, makanan yang disantapnya, dan restoran yang sering dikunjunginya, tempat hiburannya, merek-merek (baju, pena, jam tangan, sepatu, ikat pinggang, kaca mata, ponsel, dan lain-lain) yang sering dipilihnya (Sobur, 2004:167).

Gaya hidup yang ditunjukkan dalam iklan politik Risma-Bambang adalah bersantai di taman lengkap dengan bacaan buku, sandal selop pria dan sandal cantik wanita, boneka penguin, dan gaya hidup ceria. Pencitraan ini seolah ingin menunjukkan bahwa kedua kandidat, RismaBambang adalah tokoh yang membangun konsep kota Surabaya sebagai kota yang cerdas (dari sisi pendidikan) dan sejahtera (dari sisi ekonomi). Pencitraan-pencitraan seperti inilah yang kerap mewarnai iklan-iklan politik, termasuk iklan luar ruang.

Yasraf Amir Piliang menyebut bahwa pada abad informasi ini, politik menjelma menjadi politik pencitraan, yang merayakan citra ketimbang kompetensi politik. Wacana komunikasi politik sangat menggantungkan diri pada citra visual (dalam Tinarbuko, 2009:xii-ix)

Pada titik ini Jean Baudrillard menegaskan bahwa pencitraan mendiskualifikasi kategori kebenaran sehingga tidak bisa lagi dibedakan antara realitas, representasi, simulasi, kepalsuan, dan hiperrealitas. Ada empat fase citra menurut Baudrillard. Pertama, citra merupakan cermin suatu realitas. Kedua, citra menyembunyikan dan memberi gambar yang salah akan realitas. Ketiga, citra menyembunyikan bahwa tidak ada realitas, lalu citra bermain menjadi penampakannya. Keempat, citra tidak ada hubungan sama sekali dengan realitas apa pun, ia hanya menjadi yang menyerupai dirinya (Haryatmoko, 2007:33). Pada fase keempat inilah fase citra telah mencapai puncaknya. Baudrillard menyebut fase ini sebagai hiperealitas untuk menjelaskan perekayasaan dan distorsi informasi dalam media. Hiperrealitas menggiring orang mempercayai sebuah citra sebagai kebenaran, meski kenyatannya hanyalah dramatisasi realitas dan pemalsuan kebenaran, yang melampaui realitas (Siahaan, 2001:7).

Pola pikir masyarakat diarahkan atau dibentuk oleh ranah visual periklanan. Kode-kode kultural dihubung-hubungkan untuk menciptakan persepsi visual masyarakat, sebagaimana yang diharapkan. Pada gilirannya, realitas yang dimiliki masyarakat (konsumen) adalah realitas yang dibentuk oleh periklanan. Bahkan realitas ini melebihi dari realitas yang sebenarnya. Inilah yang disebut dengan hiperrealitas.

Baudrillard mendefinisikan jagat hiperrealitas sebagai model-model dan kode-kode yang menentukan pemikiran dan tingkah laku. Hal ini memperlihatkan bahwa media hiburan, informasi, serta komunikasi memberikan pengalaman yang lebih kuat dan melibatkan daripada adeganadegan kehidupan sehari-hari yang dangkal (Kellner, 2010:403). Kebiasaan-kebiasaan yang dikonsumsi masyarakat inilah yang akan menjadikannya sebagai mitos.

Dalam dunia politik, mitos kerap dijadikan alat untuk menyembunyikan maksud-maksud yang sebenarnya, yaitu membuka jalan, mengadakan taktik untuk mendapatkan kekuasaan dalam masyarakat yang bersangkutan dengan "melegalisasikan" sikap dan jalan anti sosialnya (Sobur, 2004:223).

Menurut Barthes, mitos kontemporer masuk dalam cakupan semiologi. Karena dengan semiologi, inversi mitis bisa dibetulkan dan dipulihkan dengan cara memilah pesan yang dikandung ke dalam dua sistem semantik: pertama, sistem konotatif yang petandanya bersifat ideologis (dan, dengan begitu, sinisan atau ejekannya lebih bersifat langsung, tidak terbalik, atau lebih jelas dan terbuka terhadap bahasa moral); kedua, 
sistem denotatif (ke-literal-an atau kandungan literal imaji, objek, kalimat tampak jelas) yang berfungsi menaturalisasikan atau melumrahkan proposisi kelas dengan memberinya jaminan bahwa hal yang natural adalah hal yang paling naif (Barthes, 2010:172).

Berangkat dari persoalan tersebut, permasalahan yang harus dijawab adalah bagaimana mitos kelas menengah-atas yang dicitrakan dalam desain iklan politik Risma-Bambang. Tanda-tanda apa yang dapat terbaca sehingga bisa dilabeli kelas menengah-atas.

Studi ini mengkhususkan kajian terhadap tanda visual berupa gambar-gambar dan tanda verbal berupa kata-kata tertulis yang dapat dibaca dalam iklan politik Risma-Bambang berbentuk billboard. Metode yang digunakan adalah semeotika. Metode ini dianggap relevan karena iklan politik lekat dengan citra visual. Stokes (2007:76) mengatakan bahwa semiotika adalah salah satu metode yang paling interpretatif dalam menganalisis teks.

\section{Studi Semiotika}

Studi-studi tentang semiotika banyak dilakukan oleh para pakar seperti menganalisis foto, iklan, film, novel, dan lain sebagainya. Roland Barthes adalah salah satu tokoh yang menganalisis sebuah iklan. Iklan yang dipilih berasal dari sebuah majalah Prancis untuk satu merek makanan Italia (pasta, saus, dan aneka keju) yang dijual sebagai "Panzani”. Iklan tersebut memperlihatkan sekumpulan keranjang belanja berisi paket-paket pasta Panzani, saus, dan keju Parmesan, juga produkproduk segar (tomat, merica hijau, bawang, dan jamur). Barthes menarik keluar beragam makna iklan tersebut yaitu dengan cara mencari makna literal atau denotasinya, kemudian makna konotasinya. Iklan Panzani mengonotasikan "ke-italian" ("italianicity") seperti pasta dan produk untuk membuat saus; nama perusahaan yang khas Italia; produk berwarna merah, kuning, dan hijau yang mengulang-ulang gagasan Italia melalui rujukan pada bendera nasional italia. Barthes meneliti hubungan antara kode linguistik dengan citra atau gambarnya (Stokes, 2007:77).

Menurut Barthes, dalam imaji denotatif, karakteristik pesan literal tidak dapat bersifat substansial atau tetap, melainkan bersifat relasional atau terbentuk karena keterhubungannya dengan yang lain. Pesan literal merupakan pesan yang lahir dari pelucutan atau merupakan elemen sisa ketika tanda-tanda konotasi dilucuti dari imaji. Keadaan telanjang (eviktif) pesan literal ini merupakan kekosongan yang mengandung banyak makna. Selain itu, pesan literal ini bersifat utuh karena sekurang-kurangnya memiliki satu makna pada tahap identifikasi terhadap scene yang direpresentasikan. Oleh karena itu, bagi Barthes, imaji denotatif dapat dikatakan sebagai keadaan paling sempurna dari imaji. Jika ditanggalkan unsur-unsur konotasinya, imaji dapat menjadi sangat objektif dan telanjang (Barthes, 2010:30).

Di Indonesia, Sumbo Tinarbuko menganalisis iklan politik berupa reklame yang memadati pinggir-pinggir jalan seperti iklan partai politik dan calon legislatif yang dikemas dalam karyanya Iklan Politik dalam Realitas Media (2009). Hasilnya dapat diungkapkan makna-makna terkandung di dalamnya serta dialog antara tanda dengan sistem budaya yang lebih luas.

\section{Iklan Politik}

Iklan politik termasuk iklan nonkomersial. Menurut Dan Nimmo (2004:135) kendati ada kemiripan dengan iklan komersial, iklan politik memiliki sedikit perbedaan. Iklan komersial hanya mempromosikan penjualan barang dan jasa. Sedangkan iklan nonkomersial, terutama iklan politik, mempromosikan citra yaitu imbauan yang ditujukan untuk membina reputasi pejabat pemerintah atau yang menghendaki menjadi pejabat pemerintah, member informasi kepada khalayak tentang kualifikasi, pengalaman, latar belakang, dan kepribadian seorang politikus, dan meningkatkan prospek pemilihan kandidat atau mempromosikan program dan kebijakan tertentu.

Karakter periklanan, termasuk periklanan politik merupakan bagian dari fenomena bisnis modern. Tidak ada perusahaan atau partai politik yang ingin maju dan memenangkan kompetisi bisnis atau pemilu tanpa mengandalkan iklan Karena itu, selain merupakan kegiatan pemasaran, periklanan juga merupakan kegiatan komunikasi. Pada level ini, rekayasa unsur pesan sangat bergantung pada siapa khalayak sasaran yang dituju dan melalui media apa iklan politik tersebut sebaiknya disosialisasikan (Tinarbuko:2009:1).

Pawito (2009:239) menyebut periklanan merupakan suatu strategi yang sangt penting dalam kampanye dan pemasaran politik modern. Partai politik atau kandidat pemasang iklan biasanya memberikan kontrol yang nyaris sempurna terhadap iklan mereka. Akan tetapi karakter penyampaian pesar secara sangat masif dan menjangkau publik yang sangat luas dengan menggunakan media masa menandai kelebihan 
dari periklanan. Menurut Pawito, periklanan dalam konteks kampanye pemilihan membutuhkan kecermatan dalam banyak hal. Perumusan isu atau pesan-pesan dan penggunaan strategi atau teknik-teknik tertentu dalam penyampaian pesan harus cermat.

\section{Simbol}

Barthes menegaskan bahwa sebuah objek menjadi simbol tatkala simbol itu berdasarkan konvensi dan penggunaan, maknanya mampu untuk menunjuk sesuatu yang lain (Fiske, 2007:126).

Simbol adalah bentuk menandai sesuatu yang lain di luar perwujudan bentuk simbolik itu sendiri. Simbol tidak dapat disikapi secara isolative, terpisah dari hubungan asosiatifnya dengan simbol lainnya. Simbol berbeda dengan bunyi, ia telah memiliki kesatuan bentuk dan makna. Simbol juga berbeda dengan tanda (sign), simbol merupkan kata atau sesuatu yang bisa dianalogikan sebagai kata yang telah terkait dengan (1) penafsiran pemakai (2) kaidah pemakaian sesuai dengan jenis wacananya, dan (3) kreasi pemberian makna sesuai dengan itensi pemakainya (Sobur, 2004:156).

Setiap simbol berdiri untuk sesuatu yang lain dari dirinya. Lebih dari itu, simbol juga dapat berwujud artefak dan mentifak yang lebih kompleks dan beroperasi pada level yang lebih luas dari budaya sastra dan visual. Charles Sanders Pierce berpendapat bahwa makna yang dihasilkan simbol murni berasal dari konotasi kultural yang dipahami bersama (Hartley, 2010:280).

\section{Istilah Kelas}

Istilah kelas (class) terkait dengan cara untuk memahami pemisahan ekonomi dan budaya yang ada di antara individu dan masyarakat. Dalam penggunaannya, kelas mengartikulasikan posisi sosial hingga ekonomi. Orang dibagi menjadi kelompok-kelompok dengan basis faktor ekonomi (pendapat dan kemakmuran), tetapi kelompok kelas kemudian dibuat untuk menjelaskan hal eksternal dari ekonomi, termasuk di dalamnya nilai sosial, politik, kepercayaan, dan budaya (Hartley, 2010:142).

Namun Weber berargumen bahwa kelas yang mendapat hak istimewa dapat dipecah-pecah menjadi beberapa bagian yang memiliki status yang jelas daripada hanya sekadar kepemilikan. Manajer, kaum intelektual, dan jurnalis merupakan kelas dengan hak istimewa jika dibandingkan dengan pelbagai macam tipe pekerja dengan kemampuan yang mampu ditawarkan oleh pasar. Dalam analisis Weber, hal ini relevan untuk memasukkan perbedaan seperti pendidikan dan ras dalam analisis konstruksi ideologis kelas (Hartley, 2010:143).

Menurut Asean Devolepment Bank (ADB) dalam laporannya bertajuk Key Indicator for Asia and The Pacific 2010, kelas menengah di bagi menjadi tiga kelompok berdasarkan biaya pengeluaran per kapita per hari. Kelompk pertama yaitu kelas menengah terendah dengan pengeluaran sebesar US $\$ 2-4$ per kapita per hari, kelas menengah tengah dengan pengeluaran US\$4-10 per kapita per hari, dan kelas menengah ke atas dengan pengeluaran sebesar US\$10-20 per kapita per hari. Secara keseluruhan, kelompok ini meningkat lima kali lipat dari 0,4 juta pada 1999 menjadi 2,23 juta jiwa pada 2009. Secara keseluruhan masyarakat kelas menengah Indonesia banyak berasal dari kawasan perkotaan yaitu 63, 6 juta orang. Sementara yang tinggal di pedesaan berjumlah 29,7 orang (vivanews.com diakses 22 September 2011).

Menurut pengamat ekonomi dari UI, Faisal Basri, pembengkakan strata kelompok ini menjadi incaran produsen mancanegara. Sebab, kelompok ini haus mengkonsumsi apa saja. Basri menyebut, masyarakat kelas menengah ke atas mampu berobat dan menyekolahkan anak ke luar negeri, serta membeli mobil sedan (disputatio.posterous. com diakses 19 Oktober 2011).

\section{Mitos}

Mitos dalam kajian komunikasi adalah alat untuk menyamarkan atau menutupi ambiguitas dalam suatu budaya. Beberapa perluasan perannya dipahami sebagai sesuatu yang ideologis. Pemahaman mitos dari segi semiotik menurut Barthes, adalah satu mode penandaan. Ia berpendapat bahwa dalam mitos terdapat hubungan antara penanda dan petanda yang memiliki tujuan. Jadi, tanda yang terkonstruksi secara budaya menjadi penanda, kemudian memungkinkan petanda untuk dinaturalisasi. Misalnya, nama Nike menandakan tingkah laku, status, dan kelas melampaui apa yang ditandai oleh produk perlengkapan olahraga (pada praktiknya tidak sama sekali). Artinya, mitos bekerja untuk menutupi kontradiksi yang sebenarnya melingkupinya. Dalam contoh kasus ini, sebagian besar harga sepatu olahraga dalam perbandingan dengan nilai orang yang seharusnya memakainya. Mitos bekerja untuk menaturalisasi kontradiksi seperti ini dan berniat untuk mengubah sesuatu yang bersifat 
kultural (sepatu) menjadi sesuatu yang natural (just doing it) (Hartley, 2010:194).

Mitos dalam budaya massa akan dikomunikasikan produsen dengan sengaja lewat berbagai komunikasi pemasaran seperti iklan atau desain produk dalam cara pengemasan atau bentuk produk yang dihasilkan (Harland, 2006:78).

\section{Metode Penelitian}

Metode penelitian ini menggunakan analisis semiotika dengan menggunakan pendekatan semiotika Barthes. Metode ini diawali dengan pendefinisian objek analisis dan pengumpulan teks (kumpulan tanda) yang akan dikaji. Objek analisis dalam kajian ini adalah 3 buah desain billboard politik dengan ilustrasi gambar sandal selop pria dan wanita, ilustrasi gambar penguin, dan ilustrasi gambar bacaan (Risma-Bambang membaca buku di taman).

Selanjutnya akan dilacak tanda-tanda yang terdapat dalam teks. Pada level ini, analisis yang dilakukan menyangkut dimensi paradigmatik dan sintagmatik.

Dimensi paradigmatik merupakan hubungan oposisi. Makna yang dihadirkan dalam hubungan ini ditentukan oleh elemen lain atau tanda lain yang berada dalam sistem yang berbeda. Contohnya, makna sandal selop wanita akan memiliki makna yang diharapkan ketika diletakkan di atas sandal selop pria.

Dimensi sintagmatik sebagai hubungan langsung antarelemen. Artinya, sebuah kata memperoleh makna ketika disandingkan dengan kata lainnya. Contohnya, not the other baru memiliki makna yang diharapkan ketika diawali dengan kata risma-bambang.

Kedua dimensi ini dijadikan sebagai bagian dari analisis semiotika dengan pendekatan denotasi, konotasi, dan mitos yang didasarkan pada semiotika Barthes.

Barthes menyebut denotasi sebagai pemaknaan primer dan konotasi sebagai pemaknaan sekunder. Pada level pemaknaan sekunder atau konotasi inilah mitos itu dihasilkan dan tersedia. Melalui mitos, Barthes memaksudkan ideologi yang dipahami sebagai sekumpulan gagasan dan praktik yang mempertahankan dan secara aktif mempromosikan pelbagai nilai dan kepentingan kelompok dominan dalam masyarakat (Storey, 2010:109)

\section{Hasil dan Pembahasan}

\section{Desain Selop}

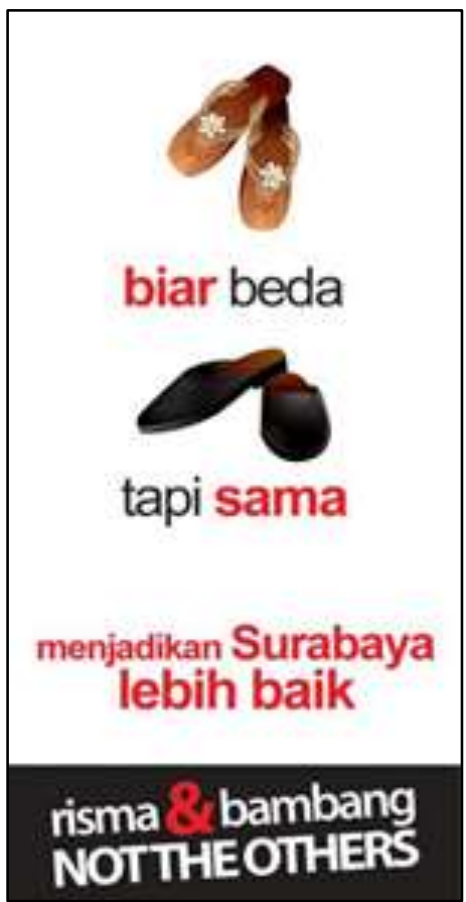

Sumber : http://nottheotherscom.blogspot.com

Gambar 1. Desain Selop

Desain Billboard pada gambar 1 terdiri atas latar warna putih, sepasang sandal selop wanita berwarna coklat, sepasang sandal selop pria berwarna hitam, tulisan warna merah dan hitam "biar beda tapi sama" yang memisahkan letak sandal wanita dan pria, tulisan warna merah "menjadikan Surabaya lebih baik", serta tagline "risma \& bambang NOT THE OTHERS" yang berwarna putih dan merah (untuk tanda "\&") dengan latar warna hitam.

Secara denotatif, sepasang sandal selop wanita dan sepasang sandal selop pria adalah alas kaki yang digunakan untuk melindungi kaki dari kotoran atau benda tajam yang bisa membahayakan kaki. Dalam tradisi masyarakat Jawa kuno, sandal selop biasa digunakan oleh raja atau keluarga ningrat (Ngatinah, 2008).

Sandal wanita yang ditampilkan dalam billboard tersebut terbuat dari kayu dengan selop atau jepit yang terbuat dari plastik dan tanpa hak tinggi. Dalam masyarakat Surabaya, sandal ini biasa digunakan wanita dalam kegiatan santai seperti ke mal, salon, hotel, spa, dan lain sebagainya. Kulit kaki tampak kelihatan jelas. Sehingga sandal ini sering dipakai oleh wanita-wanita yang memiliki kaki terawat. 
Sedangkan sandal selop pria yang digunakan sebagai pembeda (dari sandal wanita) adalah alas kaki yang biasanya terbuat dari kain bludru, oscar, atau kulit yang relatif mahal. Sandal selop hitam biasa digunakan oleh pria saat santai, di perkantoran, hotel, resepsi, dan lain sebagainya. Sandal ini sebagai alternatif sepatu pantopel yang terkesan lebih formal dan ribet.

Secara konotatif kedua sandal selop ini seolah ingin menunjukkan sebuah kondisi yang elegan tapi tetap santai. Secara paradigmatik, pemilihan sandal selop wanita dan pria tentu bukan sekadar memilih, tetapi bagaimana membentuk kode-kode kultural Surabaya tentang kesan apa yang muncul ketika ditampilkan sandal selop. Misalnya, ketika sandal selop diganti sandal jepit biasa yang samasama memunculkan santai.

Dalam pandangan masyarakat Surabaya, sandal selop dianggap lebih elegan dibandingkan dengan sandal jepit biasa yang terbuat dari karet meskipun sama-sama memiliki kesan santai. Maka, kesan elegan akan hilang jika sandal selop diganti dengan sandal jepit biasa yang dipahami masyarakat sebagai sandal yang bisa dibeli oleh siapa saja dan mudah dibeli di warung-warung kecil. Ini berbeda dengan sandal selop yang hanya bisa dibeli di mal, plasa, atau toko khusus sandal dan sepatu. Oleh karena itu, kesan yang muncul dari gambar sandal selop adalah alas kaki yang hanya bisa dipakai oleh kelas menengah ke atas. Inilah yang kemudian menjadi mitos bahwa untuk tampil santai, elegan, dan mewah maka sandal selop adalah pilihan yang tepat.

Secara paradigmatik, peletakan sandal selop wanita di atas sandal selop pria juga sebuah pilihan. Dalam budaya pratriarki, kebiasaan di masyarakat adalah pria di atas wanita. Namun dalam desain ini justru sebaliknya. Hal ini seolah ingin menunjukkan bahwa wanita juga bisa di atas pria. Tampilan ini semakin diperjelas dengan tulisan "biar beda tapi sama". Maka untuk "menjadikan Surabaya lebih baik", sebagaimana yang ditulis dalam billboard ini, masyarakat harus menerapkan budaya yang sama rata, apapun jenis kelaminnnya. Penggabungan antara kata dan gambar yang dianggap sesuai ini membentuk sintagma konsep billboard ini.

Rangkaian tulisan "biar beda" dan "tapi sama" dibuat secara terpisah dengan meletakkan dua pasang selop yang berbeda di antara tulisan tersebut. Hal ini menunjukkan penekanan konsep "sama", meski dengan jenis kelamin yang "beda".
Penekanan juga dilakukan dalam rangkaian kalimat "menjadikan Surabaya lebih baik". Kalimat ini dibuat dengan menggunakan ukuran font yang berbeda, khususnya kata "menjadikan" dengan ukuran lebih kecil. Hal ini untuk menekankan frasa "Surabaya lebih baik" sebagai inti frasa. Sedangkan tagline "risma\&bambang NOT THE OTHERS" sengaja dipisahkan dalam latar yang berbeda. Hal ini memberi penekanan bahwa frasa tersebut adalah tagline resmi pasangan Risma-Bambang. Frasa "NOT THE OTHERS" dibuat huruf besar semua untuk menekankan kepada masyarakat bahwa tidak ada pasangan yang paling tepat kecuali Risma-Bambang.

Selain itu, tulisan "risma\&bambang NOT THE OTHERS" yang berwarna putih diatas latar berwarna hitam memberikan kesan kontras dan mencolok. Kecuali warna tanda "\&" yang selalu menggunakan warna merah dalam setiap iklannya. Warna ini sejalan dengan warna merah PDIP sehingga seolah memberi ciri khas bahwa pasangan ini diusung oleh PDIP. Kata "risma" dan "bambang" ditulis dengan huruf kecil semua, sedangkan "NOT THE OTHERS" ditulis dengan huruf besar semua.

Hal ini berbeda dengan iklan pada umumnya yang meletakkan nama kandidat secara besar agar diingat publik. Iklan politik Risma-Bambang justru menggunakan kesempatan itu untuk berbeda dengan pasangan lain. Huruf kecil semua yang digunakan justru untuk menunjukkan bahwa pasangan ini seolah tidak ingin menunjukkan ke'aku'annya pada masyarakat. Justru yang ditekankan adalah "NOT THE OTHERS" untuk memberi kesan bahwa masyarakat jangan salah pilih dalam pemilihan walikota Surabaya. Tulisantulisan ini terkesan elegan dan intelektual. Dikatakan elegan karena pasangan RismaBambang tampak tidak menunjukkan sikap ambisi, sedangkan tulisan bahasa Inggris "NOT THE OTHERS" memberikan kesan berpendidikan (menengah ke atas). Inilah yang dimaksud Jagad Hariseno bahwa iklan politik ini sengaja diperuntukkan untuk kalangan menengah ke atas. Maka dalam iklan tersebut, ada yang berbahasa Inggris dengan pesan minim kata. (Jawa Pos, 3 Maret 2010). Hal ini memperlihatkan bahwa iklan politik ini tidak hanya mencitrakan kelas menengah ke atas dari sisi ekonomi, sebagaimana yang diilustrasikan dalam gambar sandal selop, tetapi juga dari sisi pendidikan yang ditunjukkan dengan tulisan bahasa Inggris. Realitas yang sengaja diciptakan inilah yang kemudian menjadi sebuah mitos kelas menengah ke atas khususnya Surabaya. 


\section{Desain Penguin}

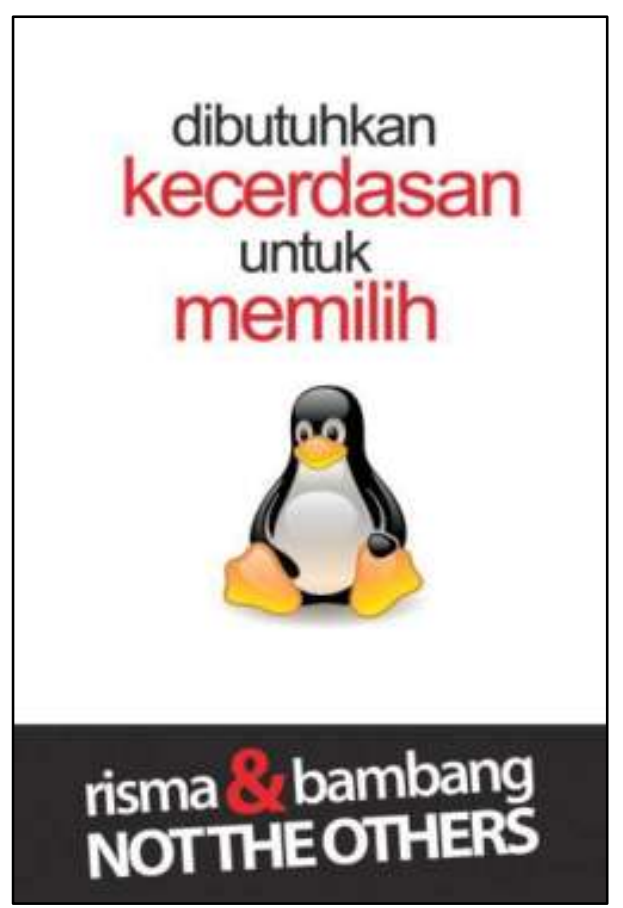

Sumber : http://nottheotherscom.blogspot.com dan http://pakdeazemi.wordpress.com

Gambar 2. Desain Penguin

Bilboard ini menggunakan hewan penguin sebagai focus of interest. Di atasnya tertulis "dibutuhkan kecerdasan untuk memilih". Kata "dibutuhkan" dan "untuk" berwarna hitam. Sedangkan kata "kecerdasan" dan "memilih" berwarna merah dan memiliki ukuran lebih besar daripada kata "dibutuhkan" dan "untuk". Sedangkan tagline "risma \& bambang NOT THE OTHERS" diletakkan di bawah ilustrasi gambar penguin. Tagline ini berwarna putih, kecuali tanda "\&" berwarna merah. Secara keseluruhan billboard ini menggunakan latar warna putih, kecuali tagline yang menggunakan latar warna hitam. Semua font dalam billboard ini menggunakan jenis arial. Sebuah jenis font yang tidak memiliki kaki.

Secara denotatif kata "kecerdasan" mengacu pada sikap yang yang didasarkan pada pengetahuan dan memiliki respon cepat. Sedangkan penguin adalah hewan yang hidup di kutub selatan. Pinguin merupakan hewan jenis unggas yang memiliki sayap namun tidak digunakan sebagai alat untuk terbang, melainkan membantunya bermanuver baik di daratan, terlebih di atas dan di dalam permukaan air. Penguin merupakan hewan yang berjalan unik. Mata penguin bekerja lebih baik di bawah air daripada yang mereka lakukan di daratan. Bahkan air sekeruh apa pun, mereka masih bisa melihat mangsanya (http://kabar- pagimu.blogspot.com/2011/11/13-fakta-seputarpenguin.html).

Secara konotatif, simbol penguin tersebut seolah menggambarkan bahwa hewan ini membawa pada sikap santai (ditunjukkan dengan jalannya) dan cerdas (ditunjukkan dengan cara kerja matanya). Fenomena ini semakin menegaskan bahwa konsep desain politik ini adalah santai dan cerdas sebagaimana yang ditunjukkan dalam gambar penguin.

Kosep cerdas juga ditunjukkan dalam kata "dibutuhkan kecerdasan" memperlihatkan bahwa masyarakat kelas menengah ke atas digambarkan dalam tingkat pendidikan. Maka penggabungan penguin dan kata "kecerdasan" digunakan untuk menegaskan bahwa untuk menjadi cerdas atau berpengetahuan tidak harus dengan muka serius tetapi dengan sikap santai. Konsep kecerdasan ini mengacu pada defenisi Weber tentang kelas, bahwa tingkatan kelas tidak hanya dilihat dari sisi ekonomi, tetapi juga dilihat dari pendidikan. Kelas tidak hanya dilihat dari kepemilikan tetapi juga dilihat dari pekerjaannya sebagai kaum intelektual. Pekerjaan ini dianggap sebagai tipe pekerja yang memiliki hak istimewa (seperti manajer dan jurnalis) dibandingkan dengan tipe pekerja dengan kemampuan yang mampu ditawarkan oleh pasar (Hartley: 2010:143)

Dalam dimensi paradigmatik, kata "dibutuhkan kecerdasan" mengacu pada masyarakat Surabaya yang dianggap belum menggunakan kecerdasan dalam memilih pemimpin selama ini. Karena itu, dalam perhelatan pemilihan kepala daerah tahun ini, diharapkan tidak sembarangan memilih calon walikota dan wakil walikota sehingga dibutuhkan kecerdasan bagi seorang pemilih. Oleh karena itu, penekanan dalam billboard ini adalah pemilihan kata "kecerdasan" agar tidak salah dalam memilih pemimpin. Kata ini diletakkan di atas penguin yang duduk berselonjor (duduk dengan kaki terjulur lurus ke depan). Maka sintagma yang terbentuk adalah sebuah himbauan memilih secara cerdas dengan simbol penguin yang duduk santai.

Sementara tagline "risma\&bambang NOT THE OTHERS" tetap menjadi tagline resmi pasangan ini. Hal ini seolah ingin menunjukkan bahwa pasangan Risma-Bambang adalah kandidat yang paling tepat untuk membentuk masyarakat kelas menengah atas yang cerdas dan santai. Maka mitos yang terbentuk adalah bahwa gambaran masyarakat kelas menengah ke atas identik dengan cerdas dan santai. Artinya, untuk bisa menciptakan Surabaya lebih baik, maka dibutuhkan pemimpin yang cerdas dengan pembawaan santai. 


\section{Desain Bacaan}

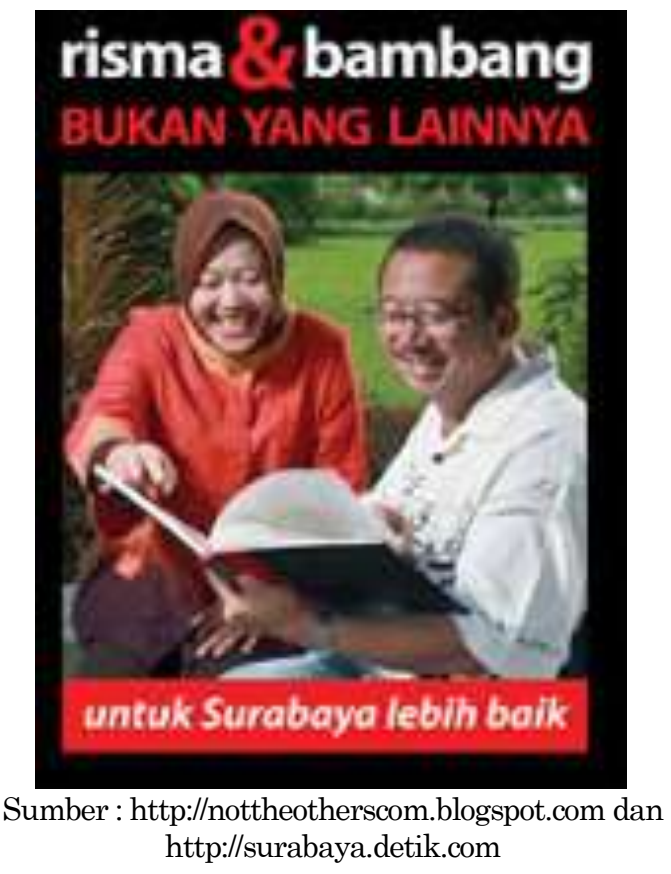

Gambar 3. Desain Bacaan

Billboard ini menggunakan desain bacaan sebagai konsep utama. Risma-Bambang diilustrasikan sedang membaca buku di sebuah taman yang asri dan hijau. Kedua pasangan ini tampak tersenyum. Risma menggunakan pakaian berwarna merah dengan jilbab warna coklat, sedangkan Bambang menggunakan kemeja warna putih dengan memakai kacamata.

Tulisan "risma\&bambang", menggunakan font arial warna putih dengan tanda "\&" warna merah. Sedangkan tulisan "BUKAN YANG LAINNYA" berwarna merah dengan huruf besar semua. Sementara tulisan "untuk Surabaya lebih baik" ditulis secara italic dengan font arial warna putih di atas latar warna merah. Kendati desain iklan ini menggunakan gambar Risma dan Bambang, namun berbeda dengan desain iklan politik lain. Sebagian besar iklan politik yang menggunakan gambar kandidat cenderung menonjolkan gambar wajah secara close up. Sedangkan desain iklan politik ini justru memperlihatkan sebuah kegiatan (membaca), bukan gambar wajah sang kandidat.

Secara paradigmatik, terdapat dua tanda visual yaitu taman dan pasangan Risma-Bambang. Pemilihan taman tentu bukan sebuah kebetulan. Sebab jika diganti dengan lapangan, sawah, atau tempat-tempat yang biasa digunakan untuk membaca seperti perpustakaan, kantor, dan lain sebagainya tentu memiliki kesan dan makna berbeda. Secara sintagmatik, relasi yang tersusun adalah relasi spasial (berdasarkan ruang) yakni satu tempat, satu waktu, dan satu jepretan (sinkronik).

Secara denotatif, kegiatan membaca buku (sebagai bahan bacaan) adalah kegiatan yang dilakukan untuk mencari informasi atau pengetahuan. Sedangkan taman adalah tempat untuk melepas kejenuhan (rekreatif). Taman terdiri atas rumput hijau dan tanaman atau bunga segar sehingga tampak asri dan menyejukkan mata bagi yang melihat. Taman juga sering digunakan untuk santai, ngobrol, atau digunakan sebagai tempat membaca yang dianggap tenang dan jauh dari keramaian. Sedangkan kacamata yang digunakan Bambang biasa digunakan sebagai alat untuk memperjelas penglihatan, terutama dalam membaca.

Secara konotatif, kedua pasangan ini tampak senang dan santai saat berada di taman. Kendati demikian, mereka tetap tampil elegan dan intelektual. Baju mereka yang tampak bersih dan kasual memperlihatkan mereka tetap tampil elegan tapi santai. Sedangkan kesan intelektual ditunjukkan dengan membaca buku di taman.

Buku dipercaya masyarakat sebagai sumber intelektual. Untuk menghindari kesan serius, maka buku dibaca di sebuah taman yang hijau, segar, dan asri sehingga memunculkan kesan santai. Senyum dari kedua pasangan juga digunakan sebagai ilustrasi agar tidak terkesan menegangkan. Artinya, kegiatan membaca di taman memunculkan kesan intelektual, santai, dan menyenangkan.

Sementara warna baju yang digunakan Risma didominasi warna merah. Ini tidak lepas dari warna partai yang menaungi. Kendati demikian, untuk mengurangi kesan sangat mencolok, jilbab risma dipadu dengan warna coklat. Warna ini menghilangkan kesan mencolok dan ramai. Karena jika memaksa menggunakan warna merah, maka konsep santai bisa hilang sehingga warna coklat menjadi alternatif untuk mendukung konsep santai.

Secara paradigmatik, jika ditilik dari warna platform partai-partai, maka warna coklat relatif tidak digunakan oleh semua partai. Hal ini seolah memperlihatkan bahwa penggunaan warna ini menghindari warna lain yang dianggap menjadi platform warna partai lain seperti kuning untuk Partai Golkar, hijau untuk PKB atau PPP, atau biru untuk PAN dan Partai Demokrat. Sedangkan warna putih untuk kemeja Bambang juga bukan tanpa alasan. Secara konotatif, warna putih adalah memiliki kesan netral, termasuk untuk 
partai. Jika Bambang menggunakan warna kemeja hitam misalnya, sebagaimana warna PDIP (selain warna merah), maka memunculkan kesan multiinterpretatif. Bisa jadi, kesan yang muncul adalah berduka cita. Hal ini akan mereduksi konsep santai yang telah dibangun dari awal. Demikian juga jika Bambang menggunakan warna lain seperti kuning, hijau, atau biru, maka akan berbenturan dengan platform warna partai. Bagaimana dengan warna merah? Tentu kesan santai akan kembali tereduksi karena semua tampak mencolok dan ramai.

Sedangkan ilustrasi tentang kacamata yang melekat pada Bambang, memunculkan kesan cerdas. Secara sintagmatik, kesan ini semakin dipertegas dengan perbuatan membaca buku. Itulah yang tampak dalam desain iklan RismaBambang. Taman, buku, bacaan, pakaian, senyuman, serta kacamata adalah unsur-unsur yang membentuk kesan intelektual, santai, dan menyenangkan. Desain iklan ini secara konsisten mengacu pada sasaran menengah ke atas, terutama dari segi pendidikan. Ilustrasi membaca di taman dijadikan inti dari mitos kelas menengah ke atas khususnya bidang pendidikan.

Dari segi bahasa atau tulisan, iklan politik RismaBambang versi bacaan ini sedikit berbeda dengan yang lain. Jika sebelumnya menggunakan tagline "risma\&bambang NOT THE OTHERS" maka iklan ini justru menggunakan bahasa Indonesia yaitu "risma\&bambang BUKAN YANG LAINNYA". Pemilihan kata ini secara paradigmatik, lebih mudah dipahami terutama masyarakat awam. Hal yang menjadi persoalan adalah mengapa tidak menggunakan bahasa Inggris "NOT THE OTHERS"? Secara sintagmatik, kata "BUKAN YANG LAINNYA" dirangkai dengan ilustrasi gambar Risma-Bambang yang sedang membaca buku di taman. Artinya, ilustrasi gambar ini telah memperlihatkan kesan kecerdasan tanpa harus menggunakan bahasa Inggris sebagai pendukung. Maka secara keseluruhan, mitos yang dibangun tetap mengacu pada konsep masyarakat kelas menengah ke atas, terutama dalam status pendidikan yang diilustrasikan dengan gambar membaca.

\section{Kesimpulan dan Saran}

\section{Kesimpulan}

Hasil kajian ini menunjukkan bahwa desain iklan politik telah melabeli dirinya dengan membangun mitos tentang masyarakat kelas menengah ke atas. Realitas ini tampak dalam desain iklan politik kandidat walikota dan wakil walikota Surabaya Risma-Bambang.
Desain iklan politik Risma-Bambang telah memanfaatkan kode-kode kultural seperti sandal selop, penguin, atau kegiatan membaca untuk mencitrakan masyarakat kelas menengah ke atas sebagai kelompok yang cerdas, santai, dan menyenangkan.

Simbol-simbol ini pada gilirannya membentuk konotasi-konotasi di masyarakat untuk selanjutnya menjadi sebuah mitos. Simbol-simbol berupa sandal selop, penguin, dan kegiatan membaca di taman sebagai kelas menengah ke atas.

Dengan terbentuknya mitos ini, seolah simbolsimbol desain iklan politik Risma-Bambang menjadi sesuatu yang wajar dan alamiah dalam menerjemahkan masyarakat kelas menengah ke atas. Pada gilirannya masyarakat memberikan pembenaran bahwa simbol-simbol tersebut untuk mencitrakan kelas menengah ke atas.

Hasil kajian ini menunjukkan bahwa sebuah desain telah mampu menciptakan persepsi visual tentang kelas sosial di masyarakat.

\section{Saran}

Kemampuan memahami kode-kode kultural di masyarakat sangat penting dalam pembentukan visual, khususnya dalam merancang iklan politik. Kemampuan memvisualisasikan ini akan memudahkan masyarakat dalam mempersepsi kandidat terkait pencitraan politik. Kendati demikian, betapapun menarik dan efektifnya sebuah iklan politik, etika desain yang menyangkut kearifan sosial dan spiritual harus tetap dipertimbangkan.

\section{Daftar Pustaka}

Barthes, R. (2010). Imaji, Musik, Teks. Penerjemah: Agustinus Hartono. Yogyakarta: Jalasutra.

Baran, S J. dan Dennis K. D. (2010). Teori Komunikas Massa. Penerjemah: Afrianto Daud dan Putri Iva Izzati. Jakarta: Salemba Humanika.

Fiske, J. (2007). Cultural and Communication Studies: Sebuah Pengantar Paling Komprehensif. Penerjemah:Yosal Iriantara dan Indi Subandy Ibrahim.Yogyakarta dan Bandung: Jalasutra

Harland, R. (2006). Superstrukturalisme: Pengantar Komprehensif kepada Semiotika, Strukturalisme, dan Postrukturalisme. Alih bahasa: Iwan Hendarmawan. Yogyakarta dan Bandung: Jalasutra.

Hartley, J. (2010). Communication, Cultural, \& Media Studies: Konsep Kunci. Penerjemah: Kartika Wijayanti. Yogyakarta: Jalasutra. 
Haryatmoko. (2007). Etika Komunikasi: Manipulasi Media, Kekerasan, dan Pornografi. Yogyakarta: Kanisius.

Kellner, D. (2010). Budaya Media. Penerjemah: Galih Bondan Rambatan. Yogyakarta: Jalasustra

Ngatinah. Karakter Busana Kebesaran Raja Surakarta dan Yogyakarta Hadiningrat Periode 1755-2005. ITB J. Vis. Art \& Des., Vol. 2, No. 2, 2008, hal. 173-196 173.

Nimmo, Dan. (2004). Komunikasi Politik: Komunikator, Pesan, dan Media. Penerjemah: Tjun Surjaman. Bandung: PT Remaja Rosdakarya.

Pawito. (2009). Komunikasi Politik: Media Massa dan Kampanye Pemilihan. Yogyakarta: Jalasutra.

Siahaan, H. M., dkk. (2001). Pers yang Gamang: Studi Pemberitaan Jajak Pendapat Timor Timur. Surabaya: LSPS.

Sobur, A. (2001). Analisis Teks Media: Suatu Pengantar untuk Analisis Wacana, Analisis Semiotika, dan Analisis Framing. Bandung: Remaja Rosdakarya.

(2004). Semiotika Komunikasi. Bandung: Remaja Rosdakarya.
Stokes, J. (2007). How To Do Media and Cultural Studies. Penerjemah: Santi Indra Astuti. Yogyakarta: Bentang.

Storey, J. (2010). Cultural Studies dan Kajian Budaya Pop. Penerjemah: Layli Rahmawati. Yogyakarta: Jalasutra.

Tinarbuko, S. (2009). Iklan Politik dalam Realitas Media. Yogyakarta dan Bandung: Jalasutra http://nottheotherscom.blogspot.com (diakses 20 September 2011)

http://surabaya.detik.com (diakses 20 September 2011)

http://pakdeazemi.wordpress.com (diakses 20 September 2011)

http://disputatio.posterous.com/\#!/pertumbuhankelas-menengah-di-indonesia (diakses 20 September 2011).

http://fokus.vivanews.com/news/read/229859kelas-menengah--magnet-bagi-investasi-asing (diakses 22 September 2011)

Jawa Pos, 3 Maret 2010, Desain Baru Iklan Risma-Bambang, Minimalis, Minim kata, dan Tidak Ada Foto 